\section{Absentees from Prague meeting}

SIR - I was shown an advanced copy of a letter from Professor Janouch shortly before its publication in Nature on 26 July (p.268). On 24 July I wrote to Dr Godfrey Stafford, President of the European Physical Society, as follows:

"The refusal of a visa to Professor Frantisek Janouch to participate in the 6th General Conference of the European Physical Society in Prague must be causing you grave concern. Janouch is not only a distinguished theoretical physicist, but also an elected member of the EPS Council, so that his enforced absence from this meeting would leave an intolerable gap in its scientific and professional proceedings.

I understand, from our telephone conversation the other day, that the EPS is taking this up with the Czechoslovak authorities, pointing out, no doubt, that their decision conflicts with the general principles on the organisation of international scientific meetings established by the International Council of Scientific Unions, and thus puts the whole meeting at risk. In support of any such representations, I should like to confirm to you in writing what I told you on the telephone - that I would not attend the Conference and give the Cecil Powell Memorial Lecture unless entry visas to Czechoslovakia are granted to all bona fide participants, including Frantisek Janouch.

I need not say that it would be a matter of deep regret for me personally not to take part in this meeting. It was a particular honour to be invited to give this distinguished lecture, and I was looking forward with great pleasure to revisiting the beautiful city of Prague, where I have many old friends. But such personal considerations are of little weight against the need to reaffirm the traditional principles of the international scientific community. I am sending copies of this letter to all the other invited speakers to the Conference, who must also have the same concern and may well be of the same opinion."

I did not make this letter public at the time, in order that further representations on this subject could be made to the Czechoslovak Government by both the EPS and the CS Academy of Sciences. I understand that such representations were indeed made, most forcibly, but it is now clear that they were not successful, and that the General Conference, together with the associated business meetings of the Council, of this distinguished international scientific society will be taking place in the enforced absence of one of its leading members. I trust that all participants in these proceedings will understand and appreciate the grounds for my withdrawal, which are precisely as stated above.

\section{Department of Social}

and Economic Studies,

Imperial College,

London SW7 2PG, UK

\section{PhD glut in Japan}

SIR - The special issue of Nature on science in India (12 April) attracted a flood of letters, whereas that on science in Japan (29 September 1983) apparently did not (see Nature 306, 220; 1983). The difference suggests that democracy, based on dialectics, is far more deeply entrenched among Indian than Japanese intellectuals. A test of this view of mine will be to see whether the response from Japan to the article by Alun Anderson (21 June) dealing with the burning issue of $\mathrm{PhD}$ glut, or "overdoctors" as they are called in Japan, will turn out to be a trickle or a deluge.

As Anderson rightly pointed out, the overdoctor (OD) problem is characterized by the indifference of the parties involved except the victims themselves. Japan's laissez-faire capitalism, the vicious competition which it engenders, in association with the hierarchical personal network which is almost the sole determinant of academic appointment and grant awards, is obviously the culprit.

It is therefore hard for those involved to raise their voices in a personally conspicuous way. Indeed, most of the activities of the OD campaign are actually run by graduate students - potentially ODs themselves - who will usually cease to be active once they have left postgraduate school for fear of offending their academic bosses.

The age distribution among academic staff in Japan will surely lead to deficiencies in Japanese science in a decade or so, but the lack of postdoctoral fellowships in Japan seems to worry overseas observers more seriously than the Japanese. In fact, I know of no article on the Japanese OD issues which is as lucid and to the point as Anderson's.

In reality, the problem is intimately linked with the university structure in Japan ${ }^{1}$. Some ambitious scientists in provincial national universities, for example, are currently struggling to open doctor courses in their universities at this very time, but are frustrated by the university and the divideand-rule tactics of the government. The OD problem is generated by elitism of the major national universities.

I cannot help feeling that the whole situation is alarmingly similar to that which led to the student protests in the University of Tokyo in $1968^{2}$. At the beginning, the students identified themselves as victims within that arch-elitist university. When the protest gathered momentum towards the end of 1968, however, the students realized that, after all, their protest was a cosy way to join the elites of which they were complaining, hence the famous slogan of "self-denial" launched at that time. For a time, the defects of the university system in Japan were fiercely debated but the outcome was that reform was shelved with the "normalization"' of the universities called for after the ugly and violent campus confrontations.

One of the features of that time was that the insurgent students did not seek solidarity with citizens in general, in contrast with what happened in Paris in May 1968. Unless the OD can surmount the barrier between town and gown, that campaign may also fail.

As for immediate remedies, government and industry should be urged to create a huge fund for postdoctoral fellowships (instead of EXPO etc.), which however should be open to overseas applicants as well, on a fair, competitive basis, with less or even no emphasis on proficiency in Japanese. University professors should be given points for their record of collaborating with ODs as co-authors of published papers. Also science shops, quite successful and widespread in the Netherlands (Nature, 7 June) to provide enquiring citizens with services in return for fees, should be considered by ODs as an alternative source of income.

ATUHIRo SibATANI

Department of Mathematics,

Kyoto University,

Kyoto 606, Japan

(on leave from CSIRO,

Sydney, Australia) 1. Nihon Kagakusha Kaigi (ed.) Overdoctor Mondai (PhD
Glut in Japan) (Shoten, Tokyo, 1983). 2. Sibatani, A. Nature 240, 191-193 (1972).

SIR - Your interesting news item (Nature 21 June, p.659) on "overdoctors"' (ODs) in Japan misses an important point. PhD students are essential in a Japanese research group not only because of the heavy teaching load of the staff but because of the need for someone to supervise the large numbers (often 50 per cent or more) of final-year undergraduates who stay on to do the two-year MSc course.

Japanese industry wants people with a first degree, prefers those with an MSc, but regards $\mathrm{PhDs}$ with some suspicion. If industry, recognizing the supervisory role of a $\mathrm{PhD}$ student during his training as well as his enhanced technical skills, were to welcome PhDs, the OD problem would be much reduced. British industry has in recent years transformed its attitude to the PhD degree, and there now exists a variety of non-university options for a graduate student who cannot, or does not want to, pursue a research career.

A.J. MACKINTOSH

Cavendish Laboratories,

Madingley Road,

Cambridge CB3 OHE, UK 